\title{
Mesenchymal stem cells immunosuppressive properties: is it specific to bone marrow-derived cells?
}

\author{
Christian Jorgensen ${ }^{* 1-3}$ \\ See related research by Yamaza et al., http://stemcellres.com/content/1/1/5
}

\begin{abstract}
Based on their capacity to suppress immune responses, multipotent mesenchymal stromal cells (MSCs) are intensively studied for regenerative medicine. Moreover, MSCs have paracrine effects, including immunomodulation that occurs through the secretion of soluble mediators, including nitric oxide or interleukin-6, transforming growth factor-beta, human leukocyte antigen $\mathrm{G} 5$, and prostaglandin $\mathrm{E}_{2}$. MSCs in the bone marrow are in close contact with T and $B$ cells and regulate immunological memory by organizing defined numbers of dedicated survival niches for plasma cells and memory T cells in the bone marrow. All of these biological effects are probably shared by all stromal cells, including fibroblasts and stem cells isolated from exfoliated deciduous teeth. The therapeutical implications are discussed.
\end{abstract}

\section{Immunosuppressive effect of stromal cells}

Multipotent mesenchymal stromal cells or mesenchymal stem cells (MSCs) are adult progenitor cells essentially isolated from bone marrow and adipose tissue and probably present in most of adult tissue, including muscle, synovial tissue, placental tissue, and recently the teeth [1]. They are currently under investigation for tissue engineering applications, in particular bone and cartilage repair, thanks to their potential to differentiate into various lineages such as chondrocytes, osteoblasts, or adipocytes $[2,3]$. They may also have a therapeutic value

*Correspondence: christian.jorgensen@inserm.fr

'Inserm, U 844, Hôpital Saint-Eloi, Montpellier, F-34295 France. ²Université MONTPELLIER1, UFR de Médecine, Montpellier, F-34967 France. ${ }^{3}$ Service thérapeutique des maladies ostéoarticulaires, Hôpital Lapeyronie, Montpellier, F-34295 France. in other clinical applications based on their capacity to limit scar formation through anti-fibrotic properties, to prevent apoptosis, to stimulate endogenous cells for regeneration, and to suppress the host immune response [4]. Such an immunosuppressive effect has been shown to occur mainly through the secretion of soluble factors by MSCs. Among the possible mediators identified, indoleamine 2,3-dioxygenase (IDO), inducible nitric oxide synthase, and heme oxygenase- 1 as well as the secretion of human leukocyte antigen $G$, transforming growth factor-beta, interleukin (IL)- 6 or prostaglandin $E_{2}$ have been postulated to play a role, but the cells need to be licensed through interferon-gamma [5,6]. These mechanisms result in the inhibition of the proliferation of $\mathrm{CD}^{+}$and $\mathrm{CD}^{+} \mathrm{T}$ cells, $\mathrm{B}$ lymphocytes, and natural killer cells that have been shown mainly in vitro but also in vivo in a number of experimental models. MSCs have also been shown to induce in vivo regulatory $\mathrm{T}$ (Treg) cells through release of sHLAG5 and it has been shown that these foxP3 cells were functional. All of these biological effects are probably shared by all stromal cells, and similar dates have been shown with fibroblast (C), unpublished data). In the previous issue of Stem Cell Research \& Therapy, Yamaza and colleagues [1] demonstrate similar immunomodulatory activities of stem cells from human exfoliated deciduous teeth.

\section{What is the role of mesenchymal stromal cells in physiology?}

MSCs in the bone marrow are in close contact with $\mathrm{T}$ and B cells. MSCs regulate immunological memory by organizing defined numbers of dedicated survival niches for plasma cells and memory $\mathrm{T}$ cells in the bone marrow. A distinct subpopulation of MSCs is characterized by the expression of CXCL12 and vCAM1. A distinct population of MSCs that express platelet-derived growth factor receptor-alpha with distinct properties is also described. Their high expression of CXCL12 and their developmental stability suggest that they might be the MSCs that 
provide a survival niche for memory plasma cells [7]. In contrast, another fraction of CXCL12- ${ }^{-} \mathrm{vAM}^{+}$bone marrow MSCs expresses IL-7. These cells are in close contact with memory $\mathrm{CD} 4^{+} \mathrm{T}$ cells and keep the $\mathrm{T}$ cells quiescent through the effect of IL-7 [8]. These results suggest heterogeneity of MSCs in terms of immune and hematopoietic functions but also suggest that MSCs have a key role to maintain immune homeostasis.

\section{Applications to immune diseases}

The immunosuppressive capacities of MSCs have been evaluated in experimental autoimmune models, as well as in humans, to prevent acute graft-versus-host disease [9]. Zappia and colleagues [10] were among the first to report the therapeutic efficacy of MSCs in the experimental autoimmune encephalomyelitis murine model of multiple sclerosis. In this model, MSCs decreased the clinical signs associated with demyelinization when injected before or at disease onset. No therapeutic effect was observed when the injection occurred after disease stabilization. The same results were observed in a model of autoimmune diabetes, in which MSC injection induced a decrease in mesangial thickening and in macrophage infiltration, resulting in the prevention of pancreatic injury. In the experimental collagen-induced arthritis (CIA) model, different studies have shown contrasted results on the role of MSCs. The first study on the use of MSCs in CIA showed that the allogeneic C3H10T1/2 cells did not exert a beneficial effect on CIA [4]. Since then, it has been reported that a single injection of primary MSCs prevented the occurrence of severe arthritis and was associated with a decrease in serum pro-inflammatory cytokines and an increase in Treg cells [11]. Similar results have been obtained in vitro and in vivo with human adipose-derived stem cells that were shown to suppress T-cell response through the generation/activation of antigen-specific Treg cells. The role of MSCs in the immune-pathogeny of autoimmune diseases and the therapeutical perspective are expected in the near future, but the optimal source of stromal cells remains to be defined.
Abbreviations

CIA, collagen-induced arthritis; IL, interleukin; MSC, mesenchymal stromal cell; Treg, regulatory $\mathrm{T}$.

\section{Competing interests}

The author declares that he has no competing interests.

Published: 8 June 2010

\section{References}

1. Yamaza T, Kentaro A, Chen C, Liu Y, Shi Y, Gronthos S, Wang S, Shi S: Immunomodulatory properties of stem cells from human exfoliated deciduous teeth. Stem Cell Res Ther 2010, 1:5.

2. Zuk PA, Zhu M, Ashjian P, De Ugarte DA, Huang Jl, Mizuno H, Alfonso ZC, Fraser JK, Benhaim P, Hedrick MH: Human adipose tissue is a source of multipotent stem cells. Mol Biol Cell 2002, 13:4279-4295.

3. Djouad F, Bouffi C, Ghannam S, Noël D, Jorgensen C: Mesenchymal stem cells: innovative therapeutic tools for rheumatic diseases. Nat Rev Rheumatol 2009, 5:392-399.

4. Djouad F, Plence P, Bony C, Tropel P, Apparailly F, Sany J, Noël D, Jorgensen C: Immunosuppressive effect of mesenchymal stem cells favors tumor growth in allogeneic animals. Blood 2003, 102:3837-3844.

5. Djouad F, Fritz V, Apparailly F, Louis-Plence P, Bony C, Sany J, Jorgensen C, Noel $D$ : Reversal of the immunosuppressive properties of mesenchymal stem cells by tumor necrosis factor alpha in collagen-induced arthritis. Arthritis Rheum 2005, 52:1595-1603.

6. Krampera M, Cosmi L, Angeli R, Pasini A, Liotta F, Andreini A, Santarlasci V, Mazzinghi B, Pizzolo G, Vinante F, Romagnani P, Maggi E, Romagnani S, Annunziato F: Role for interferon-[gamma] in the immunomodulatory activity of human bone marrow mesenchymal stem cells. Stem Cells 2006, 24:386-398.

7. Tokoyoda K, Zehentmeier S, Hegazy AN, Albrecht I, Grün JR, Löhning M, Radbruch A: Professional memory CD4 ${ }^{+} \mathrm{T}$ lymphocytes preferentially reside and rest in the bone marrow. Immunity 2009, 30:721-730.

8. Tokoyoda K, Zehentmeier S, Chang HD, Radbruch A: Organization and maintenance of immunological memory by stroma niches. Eur J Immunol 2009, 39:2095-2099.

9. Le Blanc K, Rasmusson I, Sundberg B, Gotherstrom C, Hassan M, Uzunel M, Ringden O: Treatment of severe acute graft-versus-host disease with third party haploidentical mesenchymal stem cells. Lancet 2004 363:1439-1441.

10. Zappia E, Casazza S, Pedemonte E, Benvenuto F, Bonanni I, Gerdoni E, Giunti D, Ceravolo A, Cazzanti F, Frassoni F, Mancardi G, Uccelli A: Mesenchymal stem cells ameliorate experimental autoimmune encephalomyelitis inducing T-cell anergy. Blood 2009, 106:1755-1761.

11. Augello A, Tasso R, Negrini SM, Cancedda R, Pennesi G: Cell therapy using allogeneic bone marrow mesenchymal stem cells prevents tissue damage in collagen-induced arthritis. Arthritis Rheum 2007, 56:1175-1186.

\section{doi:10.1186/scrt15}

Cite this article as: Jorgensen C: Mesenchymal stem cells

immunosuppressive properties: is it specific to bone marrow-derived cells? Stem Cell Research \& Therapy 2010, 1:15. 